\title{
ATLAS OF THE OCULAR FUNDUS
}

BY

PROFESSOR DR. OSWALD MARCHESANI

AND

PROFESSOR DR. HANS SAUTTER

TRANSLATED BY DR. A. PHILIPP M.D., L.R.C.P.S., D.O.M.S. (Llanelly)

161 Plates with 262 coloured and 13 black and white illustrations

Approx. $£ 30$

HAFNER PUBLISHING COMPANY LIMITED

STAR YARD, CAREY STREET, W.c. 2

and New York

\section{William Harvey's De Motu \\ Locali Animalum, 1627 \\ EDITED BY G. WHITTERIDGE}

Harvey promised in De Motu Cordis a further treatise, on the local movement of animals. This was never published. The notes for it, now in the British Museum, have been transcribed by Mrs. Whitteridge, who has provided full notes and an introduction.

Ready early 1959, about 60s. net

\section{The Medical World of the Eighteenth Century}

\section{S. KING}

A lively account of some of the intellectual, social, economic, moral, and technical problems which beset the medical practitioner of the eighteenth century. The author indicates a number of parallels with modern times. University of Chicago Press. 435. 6d. net

CAMBRIDGE UNIVERSITY PRESS 


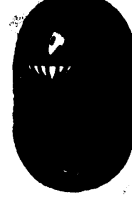

\section{S C H U M A N}

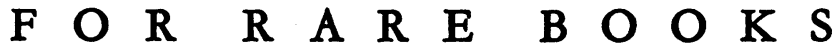
in the

\section{History of Medicine and Science}

SPECIALIZED EXPERIENCE AND CAREFUL ATTENTION GIVEN TO THE BUILDING OF COLLECTIONS IN THE HISTORY OF MAJOR MEDICAL SPECLALITIES:

CARDIOLOGY, DENTISTRY, GYNAECOLOGY, OBSTETRICS, ORTHOPAEDICS, PSYCHIATRY, PSYCHOANALYSIS, UROLOGY, ETC.

SEND US YOUR DESIDERATA WE ARE ALWAYS GLAD TO PURCHASE ENTIRE COLLECTIONS OR SINGLE ITEMS OF MERIT

Ida W. Schuman · 22 I I Broadway · New York 24 CABLE ADDRESS: SCHUBOOKS 